Так в США в случае, когда инвестиции финансировались только акционерным капиталом, предельная эффективная ставка для зданий и сооружений составила $40 \%$, а для оборудования - 28\%, если использовались оба источника финансирования, то предельная ставка снизилась до $26 \%$ для зданий и сооружений и до $11 \%$ для оборудования.

Кроме коэффициента финансового левериджа, важной детерминантой предельной эффективной налоговой ставки выступает норма амортизации. В 14 странах «Большой двадцатки» амортизационные отчисления в целях налогообложения были выше экономической амортизации. В данном исследовании при оценке предельной эффективной ставки для всех стран были установлены следующие нормы экономической амортизации: 3,1\% - для сооружений, 17,5\% - для оборудования, 15,3\% - для нематериальных активов [1]. Так в Индии, согласно положениям налогового кодекса, амортизация в налоговых целях превышала экономическую амортизацию почти на 60\%, в семи других странах это превышение составило около 40\%. Стоит отметить и тот факт, что в 11 странах более щедрые амортизационные отчисления, разрешенные к вычету из налогооблагаемого дохода, предоставляются для оборудования, нежели чем для зданий и сооружений. В 2011 г. в Соединенном Королевстве амортизация на недвижимое имущество была отменена вовсе. Предельная эффективная ставка на оборудование оказалась ниже, чем на недвижимое имущество в США, Японии, Канаде, Соединенном Королевстве. Обратная ситуация характерна для Китая, Индии и Индонезии, где наибольшие вычеты по амортизации предоставляются для зданий и сооружений. Наконец, в Аргентине, которая имеет самую высокую предельную эффективную ставку, амортизационные отчисления, признаваемые в налоговых целях, были ниже экономической амортизации как по оборудованию, так и по недвижимому имуществу. Таким образом, можно заключить, что предельная эффективная налоговая ставка выступает инструментом оценки влияния изменений в налоговой политике на уровень налогообложения различных активов.

$$
* * *
$$

1. [Электронный ресурс] URL: https://www.cbo.gov/system/files/115th-congress-2017-2018/reports/52419internationaltaxratecomp.pdf (дата обращения 11.12.2017).

2. [Электронный pecypc] URL: https://www.treasury.gov/resource-center/tax-policy/taxanalysis/Documents/New-Investment-Rates-Methodology.pdf (дата обращения 02.01.2018).

3. [Электронный ресурc] URL: https://www.urban.org/sites/default/files/alfresco/publication-pdfs/1000538Marginal-Effective-Tax-Rate.PDF (дата обращения 28.01.2018).

Рубцова В.E.

\title{
Принципы бухгалтерского учета
}

Новосибирский государственный университет экономики и управления«НИНХ» (Россия, Новосибирск)

doi:10.18411/spc-8-03-2018-12

idsp: 000001:spc-8-03-2018-12

В целях обеспечения единообразного подхода к организации бухгалтерского учета на всех хозяйствующих субъектах в российском законодательстве разработаны основные принципы его организации, использование которых является обязательным при осуществлении бухгалтерского учета.

Сущность принципов бухгалтерского учета заключается в том, что они представляют собой универсальные нормы организации бухгалтерского учета и отражения в нем хозяйственных операций экономического субъекта. 
Принцип - основа, исходное, базовое положение бухгалтерского учета как науки, что определяет все следующие, вытекающие из него утверждения.

При этом существуют различные точки зрения на количество выделяемых принципов, что отражено в таблице.

Таблицุа

Принциипы бухгалтерского учета с позициии различных авторов

\begin{tabular}{|c|c|c|c|c|c|}
\hline Принцип & $\begin{array}{c}\text { Кондраков } \\
\text { Н.П. }\end{array}$ & $\begin{array}{c}\text { Алексеева } \\
\text { Г.И. }\end{array}$ & $\begin{array}{c}\text { Лытнева } \\
\text { Н.А. }\end{array}$ & $\begin{array}{c}\text { Захаров } \\
\text { И.В. }\end{array}$ & $\begin{array}{c}\text { Алборов } \\
\text { Р.А. }\end{array}$ \\
\hline $\begin{array}{c}\text { Обязательность ведения двойной } \\
\text { записи }\end{array}$ & + & - & + & - & - \\
\hline $\begin{array}{c}\text { Раздельный учет текущих и } \\
\text { капитальных затрат }\end{array}$ & + & - & + & - & - \\
\hline $\begin{array}{c}\text { Обязательное документирование } \\
\text { хозяйственных операций }\end{array}$ & + & - & + & - & - \\
\hline $\begin{array}{c}\text { Использование учетных } \\
\text { регистров, разработанных } \\
\text { Минфином России }\end{array}$ & + & - & + & - & - \\
\hline $\begin{array}{c}\text { Оценка объектов учета в } \\
\text { денежном выражении }\end{array}$ & + & - & + & - & - \\
\hline $\begin{array}{c}\text { Обязательность проведения } \\
\text { инвентаризации имущества и } \\
\text { обязательств }\end{array}$ & + & - & + & - & - \\
\hline $\begin{array}{c}\text { Формирование учетной политики } \\
\text { в сооветствии с установленными } \\
\text { требова-ниями и допущениями }\end{array}$ & + & - & + & - & - \\
\hline Имущественной обособленности & - & +- & - & + & + \\
\hline $\begin{array}{c}\text { Нппрерывности деятельности } \\
\text { Последовательности приме-нения } \\
\text { учетной политики }\end{array}$ & - & + & - & + & + \\
\hline $\begin{array}{c}\text { Временной определенности } \\
\text { фактов хозяйственной } \\
\text { деятельности }\end{array}$ & - & + & - & + & + \\
\hline Принцип полноты & - & + & - & + & + \\
\hline Принцип своевременности & - & + & - & + & + \\
\hline Принцип осмотрительности & - & + & - & + & + \\
\hline $\begin{array}{c}\text { Приоритет содержания над } \\
\text { формой }\end{array}$ & - & + & - & + & + \\
\hline Непротиворечивости & - & + & - & + & + \\
\hline Рациональности & - & + & - & + & + \\
\hline
\end{tabular}

Таким образом, среди авторов существуют различные точки зрения на принципы бухгалтерского учета. Одним из них в качестве принципов выделяют требования к организации учета, установленные в законодательстве, другие - выделяют несколько иную группу принципов, приближенную к международным стандартам.

Наиболее часто выделяются следующие принципы организации бухгалтерского учета:

1 принцип автономности организации бухгалтерского учета построен на самостоятельности существования хозяйствующего субъекта, на отделении собственности предприятия от имущества не только его учредителей, акционеров, но и сотрудников. При этом в учете экономического субъекта осуществляется комплексное, системное отражение всех операций, связанных с движением имущества и иных активов, их управлением, с осуществлением операционной, финансовой и инвестиционной деятельности. Также в бухгалтерском учете подлежат отражению все виды обязательств хозяйствующего субъекта перед собственниками, персоналом, бюджетом, кредитными и прочими организациями. В соответствии с рассматриваемым 
принципом в бухгалтерском учете и отчетности находят отражение только те виды активов и обязательств, которые принадлежат непосредственно организации или имеют непосредственное отношение к ней [2, с. 27].

В РСБУ, в отличие от МСФО, пока нет стандарта, регулирующего учет аренды. Учетная практика сложилась так: предмет аренды всегда отражается на балансе арендодателя, доходы (расходы) от аренды арендатор и арендодатель, как правило, признают ежемесячно согласно ПБУ 9/99 и ПБУ 10/99. Правда, при лизинге (финансовой аренде) возможна ситуация, когда предмет аренды учитывается у арендатора (лизингополучателя). Но в любом случае выбор стороны, которая учитывает предмет лизинга, обусловлен не экономическими причинами, а условиями договора (юридической формой).

2 Принцип двойственности построен на использовании метода двойной записи при отражении операций в бухгалтерском учете. Данный метод отражения хозяйственных операций имеет исторический характер и является общепризнанным в международной практике. Сущность данного принципа заключается в осуществлении одной и той же хозяйственной операции по дебету одного счета и кредиту другого счета. В российской практике выбор корреспондирующих счетов осуществляется в соответствии с Планом счетов, утвержденным Минфином России [3, с. 34].

3 Принцип стоимости предполагает использование денежной оценки при отражении объектов учета [2, с. 27]. Единицей количественного денежного измерения фактов хозяйственной деятельности представляет валюта страны, это является обязательным требованием при использовании денежной оценки для предприятий и организаций.

В то же самое время существующие Положения по бухгалтерскому учету предусматривают различные способы проведения денежной оценки для отдельных видов имущества организации.

Наиболее общим правилом является формирование денежной оценки объекта имущества на основе фактических затрат, связанных с его приобретением, созданием. При этом в сумму фактических затрат включается не только стоимость, уплаченная поставщику данного актива, но и затраты, связанные с доставкой данного актива к месту эксплуатации и их доведением до состояния, пригодного к эксплуатации или иному использованию в производственной или иной деятельности, а также с оплатой услуг посреднических организаций и лиц.

В отдельных случаях для оценки имущества используется рыночная стоимость активов. Такой метод оценки используется в случае безвозмездного получения имущества, использовании отдельных видов активов (кроме денежных средств) при их передаче работникам организации в счет заработной платы и т.д. Оценка активов также может осуществляться по согласованной стоимости. Такой метод оценки применяется при определении стоимости отдельных видов имущества при их передаче в качестве вклада в уставный капитал и в некоторых других случаях.

4 Принцип непрерывности деятельности организации основан на предположении о том, что сама организация предполагает дальнейшее осуществление своей деятельности в обозримой перспективе в тех же или увеличивающихся объемах, что у руководства отсутствует намерение существенно сократить объемы деятельности организации или провести ее ликвидацию [3, с. 34]. В том случае, если все же данные моменты предполагаются в деятельности организации, они должны быть раскрыты в соответствующих формах бухгалтерской (финансовой) отчетности за текущий год, а 
также должны быть учтены при формировании учетной политики на следующий учетный год.

5 Принцип разграничения затрат предполагает осуществление раздельного учета затрат, связанных и инвестиционной и текущей деятельности организации. В соответствии с планом счетов для этого используются раздельные счета учета. В частности, для учета затрат, связанных с приобретением внеоборотных активов, используется счет 08 «Вложения во внеоборотные активы», а для учета текущих затрат - счета 20 « Основное производство», 23 «Вспомогательные производства», 25 «Общепроизводственные расходы», 26 «Общехозяйственные расходы», 29 «Обсуживающие производства».

Реализация данного принципа позволяет обеспечить осуществление соответствующей денежной оценки как внеоборотных активов, так и производимой продукции [1, с. 19].

6 Принцип временной определенности отражения хозяйственных операций в бухгалтерском учете основан на том, что отражение соответствующих операций в учете должно осуществляться в учете и отчетности того учетного периода, в котором они осуществлены, независимо от того, в каком временном периоде были получены соответствующие активы или произведена соответствующая оплата денежными средствами.

В международной практике данный принцип имеет название принципа начислений.

Исключение из данного принципа предоставляется только для малых предприятий и индивидуальных предприятий, использующих упрощенную систему бухгалтерского учета. Для данных хозяйствующих субъектов предусматривается, что отражение операций в учете должно осуществляться на момент их оплаты, независимо от фактического получения имущества или принятия работ (услуг).

7 Принцип соответствия доходов и расходов заключается в необходимости соответствия двух потоков средств предприятия: доходов и относящихся к получению этих доходов затрат. Это соответствие касается как временной определенности (доходы и соответствующие затраты должны отражаться в одном и том же временном периоде), как и видов деятельности (доходы и соответствующие расходы должны иметь отношение к одним и тем же видам деятельности, производимой продукции).

8 Принцип осмотрительности (осторожности) в западной практике носит название принципа консерватизма. Сущность данного принципа заключается в использовании определенной осторожности при формировании суждений, на основании которых проводятся соответствующие расчеты в бухгалтерском учете. Реализация данного принципа обеспечивает соответствие используемой оценки активов, обязательств, расходов и доходов их реальной оценки, позволяет изьежать их завышения или занижения.

9 Наличие денежного измерения - это количественное измерение и исчисление фактов хозяйственных явлений и процессов. В качестве единицы измерения выступает валюта страны.

10 Периодичность обобщения экономических событий. Регулярное балансовое обобщение, которое предопределено такими элементами метода бухгалтерского учета, как составление баланса и отчетности за месяц, квартал, полугодие, год. 
11 Приоритет содержания над формой означает, что в бухгалтерском учете факты хозяйственной деятельности должны отражаться исходя не только из их правовой формы, но и из экономического содержания фактов и условий хозяйствования. Например, сам по себе факт выдачи руководителем организации своим сотрудникам крупных ссуд не является незаконным. Однако если выдача этих сумм осуществляется в период неустойчивого финансового состояния организации, особенно при задержке выплат начисленной оплаты из-за отсутствия денежных средств, то данную хозяйственную операцию следует признать неправомерной.

Принцип означает основу, отражающую условия формирования и понимания концепции построения бухгалтерского учета.

Принципы бухгалтерского учета сформулированы в Положении по бухгалтерскому учету «Учетная политика организации» ПБУ 1/2008, утвержденном приказом Минфина России от 06.10.2008 № 106н (далее - ПБУ 1/2008). Они включают четыре допущения (имущественная обособленность, непрерывность деятельности, последовательность применения учетной политики, временная определенность фактов хозяйственной жизни) и шесть требований (полнота, своевременность, осмотрительность, приоритет содержания перед формой, непротиворечивость, рациональность). Таким образом, можно говорить о десяти принципах бухгалтерского учета.

$$
* * *
$$

1. Алборов Р.А. Теория бухгалтерского учета - Ижевск: ФГБОУ ВО Ижевская ГСХА, 2016. - 300 с.

2. Захаров И.В. Бухгалтерский учет и анализ / И.В. Захаров, О. Н. Калачева; иод ред. И. М. Дмитриевой. - М.: Издательство Юрайт, 2015. - 423 с.

3. Бабаев Ю.А., Петров А.М. Теория бухгалтерского учета. - М.: Проспект, 2009. - 240 с.

4. Барабанов А. Международные стандарты финансовой отчетности - Обзор // http://www.cfin.ru

5. О бухгалтерском учете: Закон РФ № 402-ФЗ от 06.11.2011 (ред. от 31.12.2017 № 344-Ф3) [Электронный ресурс] // СПС Консультант Плюс. -Режим доступа: http://base.consultant.ru.

6. Положение по ведению бухгалтерского учета и бухгалтерской отчетности в Российской Федерации: Приказ Министерства финансов РФ от 29.07.98 г. № 34н (в ред. от 29.03.2017) [Электронный peсурс] // СПС Консультант Плюс. - Режим доступа: http://base.consultant.ru.

\section{Салихов P.P. \\ Бухгалтерская отчетность как информационная база финансового анализа}

Технического Университета им. Г.И. Носова (Россия, Магнитогорск)

doi:10.18411/spc-8-03-2018-13

idsp: 000001:spc-8-03-2018-13

\section{Аннотация}

Статья посвящена обоснованию финансовой отчетности, как необходимой базы для проведения финансового анализа, финансовой отчетности и всестороннего анализа деятельности предприятия.

Ключевые слова: финансовая отчетность, бухгалтерский баланс, анализ финансовой отчетности.

\section{Abstract}

The article is devoted to the substantiation of financial statements as a necessary basis for financial analysis, financial reporting and comprehensive analysis of the company's activities.

Keywords: financial statements, balance sheet, analysis of financial statements. 